\title{
AT THE BORDER: MALAYSIAN POETS DISMANTLING FENCES
}

\section{(Di Sempadan: Penyair Malaysia Meruntuhkan Pagar)}

\author{
Muhammad Haji Salleh \\ mhs0042@gmail.com
}

Professor Emeritus

School of Humanities, Universiti Sains Malaysia, 11800 USM, Penang, Malaysia.

\begin{abstract}
The corpus of Malaysian literature representing Indonesia is quite large. From this corpus, the study chooses poetry as its genre. Applying the border aesthetics project of the Arctic University of Norway, it investigates how changing perceptions of borders relate to shifting practices of aesthetic evaluation. Two major poets who have lived and studied in Indonesia and returned are chosen. They are Baha Zain, who studied at Universitas Indonesia between 1970-1972, and Siti Zainon who studied in ASRI Jogja (1972-1974) and later lived and researched in Aceh. Both poets have written poems about Indonesia from fresh experiences or used these as vehicles into themselves. Their works were more dynamic, more thoughtful and benefitted from a comparative stance. Their language was enriched and became more colourful. Though what they experienced may be described as difficult, the final analysis, they portray themselves as friends of the country, since they participated and became part of its life and tragedies. They grew and matured with Indonesia. And it is through these many quite exceptional experiences that they interlinked the history, literatures, and writers of Indonesia and Malaysia.
\end{abstract}

Keywords: Malaysian poet, border aesthetic, Baha Zain, Siti Zainon Ismail, Indonesia, Malaysia 


\begin{abstract}
Abstrak
Korpus sastera Malaysia yang memerikan Indonesia agak besar. Kajian ini memilih puisi sebagai fokusnya. Dengan mengaplikasikan prinsip-prinsip Projek Estetika Sempadan Universiti Artik Norway kajian ini meneliti persepsi sempadan yang berhubungan dengan perubahan amalan penulis terhadap nilai estetika yang digunakannya setelah menyeberangi sempadan sastera dan negara. Dua orang penyair terkenal Malaysia yang pernah tinggal dan belajar di Indonesia. Baha Zain (yang belajar di Universiti Indonesia (UI) antara 1970-1972) dan Siti Zainon yang belajar di ASRI Jogja (1972-1974) ialah tokoh paling sesuai untuk terokaan ini. Kedua-dua penyair ini menulis puisi tentang Indonesia berdasarkan pengalaman sebenar mereka di Jakarta, Jogjakarta dan juga kota-kota lain. Karya mereka dikesan sebagai dinamik, lebih banyak merenung keadaan dan dapat mengutip faedah, terutama dari sudut kompatatif. Bahasa mereka lebih kaya dan berwarna-warni daripada sebelumnya. Walaupun pengalaman mereka digambarkan sebagai sukar, namun negara ini amat akrab dengan diri mereka, dan mereka pun menjadi sebahagian daripada kehidupan dan tragedinya. Jelas mereka menjadi matang dengan Indonesia. Melalui pengalaman yang sangat berharga ini, dua orang penyair ini telah dapat menghubungkan sejarah, kesusasteraan, dan penulis antara Indonesia dengan Malaysia.
\end{abstract}

Kata kunci: penyair Malaysia, estetik sempadan, Baha Zain, Siti Zainon Ismail, Indonesia, Malaysia

\title{
INTRODUCTION
}

The new nations of Indonesia and Malaysia are colonial constructs, born in 1945 and 1963 respectively. Before these dates, several kingdoms, including Palembang, Melaka, Aceh, Riau-Johor-Pahang, and Minangkabau extended into different parts of these two new countries. Subsequently, literary works by modern Indonesian and Malaysian writers were written before a rich tapestry of shared history, genealogies, marriages, journeys and individual lives (Andaya, 2008). The corpus of Malaysian literature representing Indonesia is quite large. Kamaluddin Muhammad, Abdullah Hussein and Arena Wati have turned their experiences into novels that narrate the intricate links between these two countries.

This paper, however, chooses poetry as its genre. Two major poets who have lived and studied in Indonesia and returned on visits are Baha Zain, who studied at Universitas Indonesia (UI) in 1970-1972, and Siti Zainon who studied in ASRI Jogja (1969-1973), have written poems about Indonesia from raw experiences or used them as a journey into themselves. 
Baha Zain stood tall before the many new experiences, yet Jakarta, Bandung and Ceribon were the background of his poetic reminiscences or journey into his own mind. In the 1970s Indonesia was recovering from its tragic recent past. The struggle for power, the grinding poverty, and on the other hand, the images of the real resilience of Indonesian people and individuals, characters from among the people (rakyat) were cast into the drama of his own life and poems, directly or indirectly.

Baha "found" himself in Indonesia. Existential questions raised by Fuad Hassan in his psychology class followed him into his thoughts. The new literary trend of searching for one's soul and finding new expression (now that political expression was curtailed) was the predominant artistic approach, and this impacted the poet. The writer, who found himself at the centre of the dynamic language of Indonesia, also found that it was seeping fast into his mind and the Malay language. Although his poems were written mostly from Jakarta, Baha however, turned particular situations into poems with a more universal significance. These are the main contours of his poems in Perempuan dan Bayang-bayang (Women and Shadows), a book that also contains some of his Jakarta poems. Meanwhile, while taking courses at Universitas Indonesia, Baha was also taught by Harsja Bachtiar, Nugroho Notosusanto, besides H.B. Jassin, Lukman Ali and sometimes by Harry Aveling. Besides literature, his subjects of choice included history and sociology-a range that enabled him to understand the past of the Indonesia he was seeing, as well as its character.

Whereas Baha came to Jakarta, Siti Zainon went to Jogjakarta. And while Baha was an established author before he came to Indonesia, Siti Zainon on the other hand has just graduated from secondary school. She was accepted at ASRI (now ISI: Institut Seni Indonesia) in January 1970 and remained there till she graduated in December 1973. She had written a few poems before that, but was really starting out as a poet. She followed the literary activities and "studied" by following the activities of W.S. Rendra, Umbu Landung Paringgi and Umar Khayam in Jogja, and Taufiq Ismail and Arifin C Nor in Jakarta. While benefitting from poetry readings in ASRI in Gampingan and Kumpulan Penyair Kampus Gadjah Mada in Bulaksumur, like Baha, Taman Ismail Marzuki became the centre of her world.

However, in Jogja she found herself close to Rendra's Theatre Group (Sanggar W.S. Rendra was near her house and she was drawn to its activities). In art she was close to Affandi and his daughter, Kartika, and her foster families Fajar Sidik/Nasjah Jamin/ Abas Alibasjah/Nyoman Gunarsa. She lived art and was in the best artistic environment possible. 
Both the Malaysian poets represented Indonesia as friends of the country who partook in its life, celebrations and tragedies. And they helped to interlink the history, the literatures, and writers of Indonesia with Malaysia.

Baha and Zainon undertook border crossings, an experience or an assortment of experiences that are usually traumatic, life-changing and having great impact on the poets' lives and later on their writing. This paper, which attempts to study the poets, is facilitated by recent border studies theories that draw a focus on the meaning of such crossings. One of the theories is Homi Bhabha's border poetics which points out in The Location of Culture (1994) that:

The theoretical recognition of the split-space of enunciation may open the way to conceptualising an international culture, based not on the exoticism of multiculturalism or the diversity of cultures, but on the inscription and articulation of culture's hybridity. It is the in between space that carries the burden of the meaning of culture, and by exploring this Third Space, we may elude the politics of polarity and emerge as the others of our selves.

Next is the website of "The Border Aesthetics Project of the Arctic University of Norway", (2014), which:

... investigates how changing perceptions of borders relate to shifting practices of aesthetic evaluation. The project draws upon two guiding observations that must inform any notion of a border aesthetics, these being a) that aesthetic theories and practices regularly invoke and engage with notions of the border; and b) that borders are in turn capable of producing aesthetic effects and can themselves be conceived of as aesthetic objects.

\section{A SHARED BACKGROUND}

Baha and Zainon came from a Malaysia of the early 1970s, when several things were happening at once. In 1969 major race riots greatly damaged the country's experiment with multiracial politics. This partly led to programs to help the indigenous Malays to gain a part of the economic cake that they seemed to have forgotten. Among these were programs to encourage further studies for students and government servants. As their choice of universities was often those in foreign countries they too experienced a border crossing. Some went to Australia, the USA and England, while others chose Indonesia for particular reasons.

To travel is to cross many borders and territories quite unknown or only partly known. One crosses geographical borders, from the Peninsula to the 
island of Java for example, into cultural territories different from one's own, where the values and ways of life are quite dissimilar. To these we must add the religious and linguistic differences, all of which are no simple journeys or crossings. Especially for practising poets, a different territory of literary aesthetics and practices is a conflicting experience, yet on the other hand quite exhilarating, and facilitating his or her own growth.

For Baha and Siti Zainon the geographical crossing was not without difficulties, yet comparatively easier, that is, going into another tropical country whose inhabitants were predominantly brown people. But it must be said that though they came from Kuala Lumpur, it was a less populated city with less economic problems. The extreme poverty that they saw was quite heart-breaking for them-and they would have to adjust to it and negotiate their way and lives around it. Jakarta of course was heavily populated, quite drab, and at that time, almost dysfunctional. It loomed large over the poet's life, pervading waking and sleeping hours-an effect which life in Kuala Lumpur perhaps did not have. In Jakarta, old forms of transportation-oplets and bemos and rickety buses run recklessly along its main trunk roads, often making sudden stops to pick up passengers. It is fast-paced but disquieting to the writer unused to this bustle. Note that we are dealing with writers, people who perceive more than the general man in the street. He or she would be affected more by tone of voice, emotions on faces, house rented-often without electricity or running water. Baha Zain came from Petaling Jaya, known as the new satellite town of Kuala Lumpur, at that time a residential town with bungalows and terrace houses. His house in Section 17 was a "showcase", comfortable with good roads leading from his section to the city. However, in contrast, his Rawamangun rented house was not in Blok M, Petaling Jaya's equivalent. Roads in the area were not paved, still made of gravel and under construction. The easier life in Kuala Lumpur had to be replaced by a more difficult one here.

On the other hand, the social environment was described as:

... sungai yang basah

Menampung segala najis cinta sedih gelandangan

Ciliwung tempat kami mengadu dugaan
... the wet river

Bearing excrements of every

wanderer'sunhappy love

Ciliwung is where we

battle trials 
Gelandangan esok akan pergi

Menyepi, menyepi, tebing

Ciliwung

Yang basah dan bertenaga

mengalir lagi

Keseorangan.
Tomorrow the wanderer will go

Lonely, lonely, to Ciliwung's banks

Ciliwung

Wet and active,

flowing on

Alone.

This is a scene where Ciliwung is at the centre of the canvas. It accepts everything - the lost loves of the gelandangan (vagabond) and the homeless, and also where they confessed their predicament, learnt to be brave and soon leave it behind. This poem is a period piece of the 1960s and early 1970s, when Jakarta was facing an influx of migrants from villages throughout Java, to become a blot on the city and Indonesia for many years. The migrants lived under bridges and by the Ciliwung river, a source of water, and as Baha says, of life itself. It highlighted the economic disparity between the classes and widespread and unresolved problems of the country.

For the poet it was a meeting with both the familiar and the different. The familiar was the people-the same physical Malayo-Polynesian features as his and generally the same religion -but surprisingly, with a quite different way of life. As Meena Alexander notes in Poetics of Dislocation (2009), many are the ways of dislocation-moving, resettling and finding a new home and identity. For Baha and Zainon there was indeed some "dislocation" from the old place, the old ways. They found themselves in a borderland of space, culture and experiences. This was quite emphatically noted, from the time they landed at the airport, Baha at Kemayoran and Zainon at Adi Soedjipto in Jogja, what they saw from the taxi, to their first residence.

Baha does not describe the physical scenario much, but Zainon often depicts this on her sketch pad in lines and forms, more than in words. However, her 2003 poem, entitled "Sepanjang Jalan Kenangan" in Witir Sela Merapi (2004: XXXI) tries to trace her earliest experiences of 26 Oktober 1969, (2004:2):

Kupaut dingin Yogya

Dari stesyen Tugu

ke Karangwuni

Kota Merapi, oh kota Merapi

Nama kubawa sejak muda ...
I cling to the cool of Yogja

from Tugu to Karangwuni

stations

Merapi city, oh Merapi city

a name I've carried since my youth... 
She goes on to describe her arrival at Karangwuni at the foothills of the Merapi, at once romantic and green, but also tantalizingly dangerous (2004:2):

$\begin{array}{ll}\text { Kau bawa usia pertamaku } & \text { You endured my early years } \\ \text { Memasuki pintu luas } & \text { Through wide doors } \\ \text { Jendela ukir masih berjeruji } & \text { Carved windows still grilled } \\ \text { Di perayaan hari jadi } & \text { On birthday celebrations } \\ \text { Terhidang uji } & \text { Served with tests } \\ \text { Aku harus tumbuh di sini! } & \text { I should grow here! }\end{array}$

At the Saptohidoejo Gallery, with its wide doorway and carved windows, on her birthday she was fed with challenges -for it was here that she must grow.

Like Baha, Zainon too had some sort of preceding journey of introduction to Indonesia and the Indonesians in the late 1960s. Her step-father owned a printer's shop. Close by was Pustaka Ubor, which sold Malaysian and Indonesian books. To this shop came Malaysian writers and also Indonesians in transit or even escaping Sukarno. Among them were Sutan Takdir Alisjahbana, Moechtar Loebis and Saptohidoejo. They exchanged notes and ideas, and mostly debated-not so quietly-in Indonesian. When she first met Nas Achnaz, her art teacher, Malay novelists like Arena Wati, Abdullah Hussain and other friends were gathered there too, all speaking in Indonesian. This was an introduction, though far from complete. It was in fact Saptohoedojo who encouraged and invited her to Jogja if she wanted to study art. This invitation she accepted and for a while she stayed in his gallery/house.

Zainon's reaction to Jogjakarta was gentler than Baha's, and not least because it was a gentler city. Her reaction was very positive and she came to like it there, particularly the protection of big names and families of artists.

Her early Jogja poems were sensitive to the background and history of the Javanese, their culture and folk arts. Thus the images of Borobudur, Prambanan, tempe, and the Bringharjo, bird and cattle markets-the real life as it was lived there-fascinated the poet.

The poems of Baha and Zainon did not portray disappointment at arrival, but instead showed a sincere desire to find meaning in the place where they resided. In this respect Baha also tended to describe the tired and sweaty face of Jakarta in the early 1970s. But Zainon on the other hand, was quite 
excited by all that was new that Jogjakarta offered, its markets and people and folk arts, and not least the magical world of the contemporary art of Jogjakarta and ASRI.

Here is a real life description of a colourful, noisy and foul-smelling cattle market (2004:4):

Peraih dan pembeli
Saling bertengkar sebelum
jenaka
Meletak dan menawar harga
Tapi kau bertanya ke diri
Sempurnakan makan anak
penternak sapi.
...

Traders and buyers

Argue before they jest

They put a price, bargain

But you ask yourself

Does the herdsman's child

have enough to eat

The noisy bargaining and humour is portrayed, while she says: "when you bargain the price do you also think whether it's enough to feed the children of the herdsman well?" They could not but observe with the eyes of the artist, and also with the eyes of sensitivity and empathy.

They were often enthralled (and sometimes tired out) by the intensity of the literary and artistic life. Taman Ismail Marzuki was a great inspiration, a place to watch plays, readings, and absorb Indonesia's literary and artistic soul and innards. Baha says that the multi-artistic offerings and noisy new life made a great impression on him. ASRI was the centre of artistic life in Central Java where many of the most important artists came or taught. There was thus also a subconscious fascination for these differences for the Malay poets at Jakarta and Yogja. They began or continued to observe the artistic scene and people they have not encountered before. They heard unique poetry readings, imaginative plays and dances. There was also a sense of a sharpness of realization and hence a comparative starkness of contrast.

Jakarta haunted Baha Zain-the images and the places were quite unspecific. In "Wajah-wajah bundar yang pekat", (Round, thick faces) he says (1974:17):

garis-garis penuh lesu

pada subuh sore atau malam pada wajah pekat dan bundar di mana-mana aku menunggu seperti siapa pun tak bisa lari dari garis dan wajah ini. lines and lines of weariness at dawn twilight or night on round gloomy faces wherever I pause as if no one can run from these lines and faces 
The faces, thick and round are there in the dawn, afternoon and evening. They are the people, and the people are the country, defining it with their faces and identity. To be in another country is to be with its people and its special character.

\section{WORDS FREED FROM DETENTION}

The people and the happenings often pulled the poet to the core of their lives-and they could not but become more involved. Their neighbours were hawkers in the markets and also the homeless under the bridges. Baha (2014: personal communication) ruminated over the hawkers who carried their ware endless on their shoulders and backs for a piece of rezeki, daily bread, often a pittance. They were hawkers of kerosene, sekoteng, bakso, vegetable and fish, and not least the mattress carrier sweating away in the hot afternoon carrying bedsteads of uncured young wood. Each had its own iconic sound-however, mostly sad, sounding like mournful pleas to fate.

But it must be said that the poets came as young poets and artists just starting out. It was in this territory of dislocation that they remade their self and works, which we may look at to find evidence of reaction, interaction and change.

Baha went to UI, Rawamangun, for his classes, while Siti Zainon to ASRI. The latter describes what it means to be there-here the metaphor is that of a garden. It was here that she planted a seedling (a metaphor for the poet's own self), which was to grow and flower in a garden of many plants, flowers and colours.

$\begin{array}{ll}\text { ASRI } & \text { ASRI } \\ \text { Di sini } & \text { Right here } \\ \text { setelah menanam pohon } & \text { upon planting a tree } \\ \text { mentari selalu jatuh } & \text { the sunlight always falls } \\ \text { memberikan warna } & \text { offering colours } \\ \text { hijau atau kuning } & \text { green or yellow } \\ \text { di tamanmu. } & \text { to your garden. } \\ \text { biar } & \text { let } \\ \text { seketika angin mengusik } & \text { a momentary wind tease } \\ \text { menjentik bunga-bunga kecil } & \text { ruffle small flowers } \\ \text { sebelum embun berderai } & \text { before the dew scatters } \\ \text { cepat sekali serinditmu } & \text { how quickly your parrot } \\ \text { memecah rinduku. } & \text { breaks my loneliness }\end{array}$


There is gratitude and longing, she finds happiness here in this garden that she came to. Both poets wrote partly about Indonesia, and partly of their interaction with the country. They might sketch a scene and relate the external scene of a personal emotion or predicament. So they interacted with physical Indonesia, at the same time linking it (subconsciously) to the internal self. A case in point is Baha's "Seperti kelahiran diiringi kesakitan ..." where he describes his loneliness when there was no word from home. This loneliness is expressed in nature like a pantun. Birds, standing stiff and wet, understand his predicament (1974:24):

\begin{tabular}{|c|c|}
\hline pohon-pohon berdiri kaku & trees stiffly stand \\
\hline pada sore yang basah & in the wet twilight \\
\hline $\begin{array}{l}\text { tak ada berita dari jauh akan } \\
\text { mengganggu }\end{array}$ & $\begin{array}{l}\text { no news from afar } \\
\text { to disturb }\end{array}$ \\
\hline sekawan burung memandang & a flock of birds watch \\
\hline amat mengerti & with full insight \\
\hline kepedihanku menanti & my stinging anticipation \\
\hline lidah senja menjilat petang & twilight's tongue licks the evening \\
\hline$\cdots$ & \\
\hline dan pada malamnya nanti & and later at night \\
\hline akulah narkisus & I am the narkisus \\
\hline
\end{tabular}

\section{THE LITERARY SCENE}

In 1970 H.B. Jassin and Moechtar Lubis were still the most dominant and influential figures. In the second rung we find W.S. Rendra, Subagio Sastrowardojo, Ramadhan K.H., and Ajip Rosidi, and below that, Goenawan Mohamad and Taufiq Ismail. In Jogjakarta, Kirdjomuljo, W.S. Rendra and Umbu Landung Paranggi were the more senior writers. Pramoedya Ananta Toer, a dominant novelist and polemicist. Sitor Situmorang and many other LEKRA were detained on Buru Island, Salemba and elsewhere.

In Jogja, outside the capital, the issues were less political, but with discussions about Rendra's upcoming play, Mastodon dan Burung Condor. This long play purported to dramatize the antics of prehistoric animals, but it clearly echoed contemporary acts of the Suharto administration loudly. The works of Umbu Landung Paringgi were also given space.

Thus in the Soeharto era the socialist writers were not represented and open discussion was only beginning to be rediscovered. Political issues were dampened within the writings of the poets and critics. Thus freedom 
of expression must be sought in-between the lines, and behind the curtain of metaphors. Only Rendra protested (for many years), strongly and directly expressing his frustration on behalf of the poor and helpless.

Zainon found the literary scene in Jogja to be quite lively. There were poetry readings, discussions, and plays. On campus there were several sanggar, workshop for writers, as well as those for performing arts-the dancers and artists.

\section{THE TIMES}

Indonesia has always given space and voice to hers intellectuals. In the late 1960s and early 1970s French philosophical schools like absurdism and existentialism crept into the works of Iwan Simatupang, especially Ziarah and Merahnya Merah. Both of them, who did not find much meaning in a bigger organization of things or in society itself, what more the future. The French schools of existential thought were also linked to the French Resistance during WWII, and saw meaning in a real rebellion against injustice. Baha was attracted to them. Now that questioning political and social problems was only selectively allowed, writers turned and returned to their personal predicament and situation. Existential questions which Fuad Hassan raised in his classes followed Iwan into his lines. The new literary trend of searching for one's soul and finding new expressions also became his (1974:22).

\author{
dan dari pandanganmu \\ kutemui diriku \\ di teluk yang hijau \\ sejuk-sejuk belayar.
}

\author{
and from your eyes \\ I found myself \\ in a green bay \\ coolness sailing away.
}

Baha has also written a poem called "Metamorphosis", describing a person/poet who has come to the conclusion that there is nothing much to trust in human beings, "Bagi siapa pun namanya kini kepercayaanku sudah tiada lagi". And this no doubt related to "Topeng-topeng" (1974: 34), among his most well-known poems written in the capital. The world is but a house of masks, because of its failures:

$\begin{array}{ll}\begin{array}{l}\text { ini dunia menjadi rumah } \\ \text { topeng-topeng }\end{array} & \begin{array}{l}\text { the world is a house } \\ \text { of masks }\end{array} \\ \ldots & \ldots\end{array}$


ini dunia menjadi rumah

topeng-topeng

....

bagi mereka yang gagal

berikhtiar

bagi mereka yang besar

berdoa

berkacalah dengan

topeng-topeng

dari bayang ke bayang. the world is a house

of masks

...

for those who fail

to strive

for those who are big

on ritual prayer

shattered by

masks

from shade to shadow.

He has not much faith in politicians-now this faithlessness spreads to others, who he sees as performers behind the wayang-not their real selves, but wearers of masks.

$\begin{array}{ll}\text { di sekitarku topeng } & \text { around me masks } \\ \text { di sekitarku mereka } & \text { around me they } \\ \text { ini aku } & \text { this is me } \\ \text { wajah telanjang } & \text { barefaced } \\ \text { di muka kekonyolan. } & \text { in the face of foolishness. }\end{array}$

Not that there are no masked Malaysians, but he realized this stark and profound fact while in Indonesia. Later Leila Chudori too (independently) wrote about the great number of masks in her short story in the 1980s.

In the meantime Siti Zainon discovered her poetic talent which had begun only a few years before coming to Jogjakarta as a student. And most importantly it was her artistic talent that bloomed forth under the mists, and sometimes ash, of Merapi. But she nurtured both these obsessions through constant practice, and in the excitement of her youth and borderland.

She sketched in words as she sketched in lines and ink. We see a journey into Jogja and the Indonesian soul being described at various points. In a poem quoted earlier it begins with her arrival and her introduction at Karangwuni. It was here that she made many friends and forged gentle emotional ties with them. These are the transcultural friends, and not to forget, her grand transcultural mentors-Affandi, Moechtar Lubis, and H.B. Jassin. Also helping her was Prof. Suminto Sayuti.

All these were sketches of herself in interaction with Jogja and its inhabitants. In them we see Zainon, the quiet seeker of art and words and love, which became symbols in most of her poems. 


\section{TRANSCULTURAL RELATIONSHIPS}

In Jakarta and Jogja, the poet was in a border zone/a border crosser and also a writer with experiences in two cultures (at least) with a clear subconscious (!).

Baha and Zainon made friends-these friendships were special because they were "transcultural friends" from another culture and another literature, as pointed out by Gomez-Pena (2006). Baha's classmates included the late Dami N Toda and Yasser, who were yet like him still absorbing and learning their art from the times and the professors. Baha knew Goenawan Mohamad and Taufiq Ismail. These were his transcultural friends. He went to H.B. Jassin's library often and learnt from his detailed and painstaking approach and care for manuscripts and books -as well as from other writers and critics. In the meantime Jassin also became his academic (transcultural) supervisor and mentor. Baha, and later Zainon, were witnesses to his unending conscientiousness and patience-his great humanity. From him and his library they also learnt of other important writers and where to find them. On his return Baha set up a section in which all written documents by Malaysian writers were collected in the Dewan Bahasa dan Pustaka Library, a section this is quite alive today- 40 years on.

Baha often remembers his evenings in TIM, which offered poetry readings, forums and also plays and wayang performances. However, he did not record them in his poems as Zainon did for her Jogjakarta experience. Earlier there were very few writers included in her lines, but later we see letters of friendship and encouragement from Moechtar Lubis, H.B. Jassin, and Prof. Suminto Sayuti. These were her transcultural mentors and teachers.

As noted above the main authors in Jogja, besides those mentioned earlier, were Rendra and Umbu Landung Parranggi, who liked to befriend young authors to help them along in their writing. Her friendship with them has been enduring. However, we must add that beyond the literary and artistic circles, they made friends with their neighbours and other Malaysian and Indonesian students and foreign visitors. However, Baha confesses that his circle was quite small in the beginning. Siti Zainon, the young and inquisitive poet-artist had many friends, as mentioned above.

\section{THE LINGUISTIC BORDER AND ITS NEW POETIC}

We have described geographical, social, and some cultural borders that these poets entered. The linguistic border was intricately complex, abstract and often a subconscious one. With claims of similarities between the two 
languages, and that the Indonesian language has its roots in Malay, one does not often consider that Malay and Indonesian are in fact practically different languages-different enough to present great dissimilarities and problems of ambiguity and misunderstanding. As duly recognized, before 1945 Indonesian was based on the Malay of Riau which was also the Malay of Johor and Singapura. In the Malay hemisphere, one does not think of the two languages as separate. But Malaysians and Indonesians alike know now that since the 1950s, when they crossed over the border, there were indeed many differences that make a full understanding impossible and even block it totally. Malaysian Malay is more classically based and also heavily influenced by Sanskrit, Arabic and English. Whereas Indonesian on the other hand has many influences, from Dutch and Javanese, Betawi Malay and many other languages of the islands. Grammar also follows some European rules of Dutch, while in Malaysia it is English. Syntax is also problematic for the border crosser, especially for speech.

Ironically, the two branches of the language are now on the one hand, getting closer, especially with terminology (not least through agreement, and also by border crossers who reuse the terms of each other in their own country). However on the other hand, for special needs, history and usage, it is becoming more different in both countries. The Indonesian of pre-war years was markedly closer to the Malay. After that it moved further away from familiarity for their neighbours across the waters. But poets who read both literatures and other mass media, came to be quite aware of these differences, and negotiated the area in between. The problem though was that as soon as one begins to understand the current colloquial expression and terminologies (some of course with the help of dictionaries and Indonesian friends, and others by guess work), it has already changed again and one has to start learning a new vocabulary! Indonesian is changing too fast even for admirers of the language (from across the Straits), especially in the Jakartan lingo of young Indonesians.

For many practising Malay writers, Indonesian is a different language. However for some others this is partly not the case, as Indonesian literature was taught in Malaysian schools and universities in the 1960s and even till now. And in Penang and Kuala Lumpur there were fairly good libraries stocked with important literary works.

But with Malay in their psyche, encountering spoken Indonesian in Jakarta and Jogja would indeed be a real and tangible crossing of linguistic borders. While Malay is more classical and literary, Indonesian was created 
and developed to handle a great archipelago of more than 1400 languages and new ideas and discoveries in the arts and sciences. It has become dynamic, receiving creative minds and literary traditions from the different islands and languages of the Archipelago, and the world-to its gain. The Malay language is not as dynamic and for the newcomer to Indonesian he or she cannot but be hypnotized by its magic. Especially for the poets whose single instrument is the language, Indonesian showed the way in the sciences and many other fields of knowledge-especially its terminologies in the various fields of studies and research. Experimentation with vocabularies of the old and new Indonesia and novel creations from its imaginative and brave writers have contributed to different and elegantly unique ways of expression. These have caught the imagination of Malaysian writers, including Baha Zain. I have collected some examples of "borrowings" from Indonesian by the poet, some not from the imaginative genius of Indonesian, but necessary practical phrases needed for survival:

Keberadaanmu dan keseluruhanmu - from "Keseluruhanmu"

Sore kurungan duka - "Air mata"

Dingin - "Air mata"

Tak bisa - "Air mata"

Horison - "Sketsa anak kecil"

Lelah - "Dalam lingkaran"

And terms like, pacar, filsafat, pajar, monumen, iseng, Roman, ganggang and kekonyolan, popular in Indonesia, were unfamiliar to the poet. However, they sounded nice and new in their lines. And there are also many other popular terms that would be unknown or known only in the Malay form, albeit with different meanings.

Zainon's case is interestingly different. She did not come into an Indonesian language area, rather it was a Javanese zone. Most of her mentors and friends spoke Javanese, which she found to be gentler than Indonesian. And as she moved along mostly with the Javanese, she also moved along with the Javanese language which seemed to suit her personality and outlook. It was the high Javanese that she favoured. Zainon confesses, (2014: Personal Communication):

Saya memasuki dunia Jawa. Bahasa Jawa Halus bersama ibu-ibu angkat dan bahasa Jawa kasar daripada lidah para remaja. Untuk melukis rupanya 
saya memilih bahasa santun, lembut bunyinya sehingga saya terpengaruh nada "alon-alon waton kelakon" - perlahan-lahan, berperi laku.

I entered into the Javanese world. The language of High Javanese with foster mothers, and low Javanese from the lips of youths. To paint it I had chosen the language of politeness and its gentle sounds, and was influenced by the tone of "alon-alon waton kelakon", that is, the gradual and gentle of speech and style.

In her poems she chose the polite, gentle sounds, so that I was influenced by the "alon alon waton kelakon," with its gentle expressions and slow-andsteady nature, and polite yet aesthetically pleasing. Listen to these smooth and gentle-flowing lines from "Perawan Bulan Yogya", (2004:5):

Wajah mudamu
muncul di puncak Pramabanan
di bawah pintu, Kalamukara,
jarinya hampir menyentuh ubun
kau perawanku
terlalu muda sinar bulan
percik ke keningmu.

\begin{abstract}
Your fresh young face emerges above Prambanan peak below the doorway, Kalamukara fingers almost touching the crown you are my source of melancholy effortlessly the moonlight is strewn upon your brow.
\end{abstract}

The movements of the young dancer are also symbolic of the Javanese aesthetics of dance. It is this aesthetic dancing in the poem and to my mind, in hundreds of her later poems. While we may call it influence we can also see it as a similarity in personalities and a favourite parallel, thus easily imbibed and grown in the home grounds of Malaya (now known as Malaysia).

Thus in Siti Zainon's Jogja poems there are more Javanese linguistic elements in her style. However, in her vocabulary I collated these as examples of her more visible "borrowings", that is, from poems written between 1970-1973.

$$
\begin{array}{lr}
\text { Jendela- "Karangwani” } & (2004: 2) \\
\text { Penternak sapi- "Giur Pasar Sapi" } & (2004: 4) \\
\text { Aroma- "Giur Pasar Sapi" } & (2004: 4) \\
\text { Gandik- "Mimpi Lembah Serayu." } & (2004: 7)
\end{array}
$$

Besides these, there are other terms like berpupur, tempe bongkrek, jemblung, and perkutut. 
It is interesting to note that before the 1970 s these words were almost unknown in Malaysian writing, but now they seem to have crossed the border and settled quite comfortably in Malay, also not as illegals, but with the stamp of the border linguistic office. This phenomenon began with the writers and was later spread by the mass media.

For both the Malaysian writers these new words or older ones with new meanings were an interesting introduction and sounded unique in their poems. At first they sounded artificial and ostentatious, but later some of them were accepted, as they came from a Malay language of the Archipelago, and not from the colonial English language. The words provided some interesting differences for the Malaysian reader. Sometimes certain terms were used to define things that have no words in the Malay language like tempe, srimpi, gandik, and so on, as specific terms of reference.

The dominant language, Indonesian, offers various attractions and instruments that are naturally attractive to Malay writers. So for many years this was the trend, especially among young writers. But after a while there was a reversal in the trend-one that appreciated the offerings of Indonesian, but nonetheless felt that Malay too has its own instruments and qualities that are just as wonderful (Zainon 2014: personal communication) admitted this:

\section{Ya saya mula melaraskan bahasa Melayu dan ingin keluar daripada pengaruh tata bahasa dan perkataan Indonesia.}

Yes I began to adjust to the Malay language and wished to depart from the influence of Indonesian grammar and words.

We have noted how in her earlier years, Siti Zainon was influenced in her language, through the spoken (high) Javanese of Rendra and Umar Kayam. However later, upon return to Malaysia, she was to tune it back to Malay. There was a sense of realization that while she was in love with the Javanese language (and also partly Indonesian) she also needed to tune her identity as a Malaysian, especially now that she was an established poet and a well-known figure.

When Baha and Zainon came to Indonesia each had their own favourite writers from school days and from their own reading. These they considered as good examples to emulate or meet. Many were of the older generationMarah Rusli, Chairil Anwar, Sutan Takdir Alisjahbana and Achdiat Hadimadja. Some of them had been gone a few decades ago and others only a few years. Others, however, like Moechtar Lubis, Sutan Takdir and Umar Kayam were 
to be seen in Jakarta at forums and performances. They were the highlights of the Indonesian literary scene at the time.

Books were the more easily accessible sources of good Indonesian. Outside schools there were a great number of books for sale-in Senin and various other places, in Jogja in the major second-hand book stalls and also in the newly-refurbished Gunung Agung. And the two poets found a haven in them, especially since they were extremely inexpensive and tantalizingly forbidden or declared politically banned.

It was not easy to write about the soul of Indonesia, but easier to draw the pictures of Malaysia's soul-or more particularly, its face. The thoughts or of experiences that had not been intensely felt before now become more pronounced as a result of subconscious or conscious perceptions of contrast.

A by-product of their poetry was a subconscious, new way of looking at the motherland-along with a new or different way of looking at Indonesia. There might be feelings of sensitivity on both sides, or anger or disenchantment. Interesting poets don't reject Indonesia but feel it to be a great source of inspiration-through its images, ideas and people and also ideas and imagination in literature and the other arts. From this experience of myriad places and people, they embarked on a journey in a different direction-but a natural one, that is, into the self-now helped along by a comparative edge or angle-with elements of confrontation, balance, familial roots and similarities.

Sometimes the poet feels a desire to find a place beyond differenceand climb to a kind of universal meaning-that may be shared not only by these two countries bordering the Straits of Melaka, but also other people and readers from other countries. From here they could leap frog into the universal, and find a meaning beyond difference.

Finally we come to access the poetics of the poems written while the poets were in Indonesia.

Let us start by surveying the 1960 s when the two poets began to venture into Malaysian poetry for comparison. In Malaya and Singapore then, there existed a specific poetics, essentially of the engagee or committed kind, or as it was known in the Peninsula and Singapore then, "Sastera untuk Masyarakat." There was indeed a dearth of socially committed poems, often as repeated patriotic calls to awaken to a new decade and to seize opportunities that it offered. Problems of identity were often high on the list, and so was the future of the economy. The literary leaders were still Masuri S.N. and Usman Awang. On the other hand there was a thin backlash of rebellion by a group known as "Penyair Kabur" (The Vague Poets), who veered into the self, imagination, and language of symbols and images. 
In the meantime, in the late 1960s before going to Indonesia, Baha was writing poems of protest against the authorities and America. His words were more direct and harsh-a language to be shouted out. For example his "Rayuan Wanita Asia" (Pleas of the Asian Woman), described the sufferings of a Vietnamese woman driven to prostitution, with words out in her mouth (1974:12; 2008:8):

What else can I surrender now

All frangipani wilt in the fire of the blasts

You have filled all wombs

With your dollar

With your V.D.

This is an experience partly felt outside the self-the sense of anger that human beings were violated, especially the helpless woman. This happened in the midst of the Vietnam war. But in Jakarta, his poems were more ruminative, and quite visibly explorative. A language of thought was slowly being constructed for his special use, before his special predicament. The words often moved more slowly, and more abstract lines of ideas and images were offered to his readers. In the following poem, "Woman", for example (1974:32; 2008:6):

My woman, you who are created from smoke, steam, mist and cloud

How thick is the night silk that wraps all dreams

How far the distance between myself and your secret

Like a flourishing green jungle

Impenetrable to the light

Like the scent of falling leaves filling my lungs and breath

Like the smell of a baby suckling your breast

Boundless joy

Boundless danger

Woman, I'll ride you on to the wide open fields

Like the neighing of a horse

Your voice echoes into the unknown

Swallowed by the stillness but the dust at your feet blurs all sight

You gallop on ceaselessly from one field to another

No one ever knowing the colour of the hair that wraps your body. 
The poet has come to understand the different terrains of life, of the ways of the people, and drawn a map of complex and intricate images, scenes and crowded panoramas. He has gone inside the problems and had more time to mull over them more seriously, which he could not do in Malaysia. Consequently we see approaches which are no longer simple or simplified. His analysis is also similarly multi-faceted and takes into consideration social values and the human heart-all of these are not easy to convey, even in poetry.

Baha also experimented with a narrative style-more "psychological" to use his own term. For example in "Sketsa Anak Kecil" (1974:23; 2008:4) in which a child draws with total freedom, caring little for the real colour or place of the sun and the moon, but splashes his tints according to the magic of his imagination.

\section{I}

Oh Sun,

I hang you on the horizon

Oh moon,

I set you between the tree's crown and the clouds

May you rest there

And not have to climb higher

I love to see you from this window.

II

Oh Sun,

Tomorrow I shall paint you green

But moon,

If it rains tomorrow evening

I shall reserve black for you

Because you are not cheerful

And I am forever sad.

\section{III}

\section{I cannot again}

Place you as my heart desires

Over the bamboo leaves, besides clouds, on the horizon,

I must leave you

To rise

Though you are black or green

And I myself am

Plunged deep

In your shadows. 
The child has found total freedom, a scene that may be found glinting vaguely in a poet's dream. However, this child is the mask of the poet, the dramatist personae tasting his new freedom and acting on it. Here the child transforms into the poet, and the crayons into his words and literary instruments. Baha tried to fish in a bigger sea, though with a small net of efficient and tried and tested language.

The border poets had remade poems after their own selves which had been changed by the various geographical, cultural and linguistic border crossings.

\section{CONCLUSION}

The borderland presents the poet with the taste of difference, and different meanings. However, when the writer himself is involved, it is the meaning of the experience at the border that counts. In the final consideration what is sought is the meaning of life itself. In this way the meaning may take on a more general significance. It transcend barriers and makes lanes and bridges for us to cross. These poets represent the more reasonable and altruistic side of us. The borderland helps in bringing peoples together when the situation is right.

Both poets have experienced a "transition abroad." This is closer and kinder than dislocation-though there was an element of temporary dislocation which showed itself quite clearly. For Zainon and Baha undoubtedly there was a crossing and then dislocation-but only for a short while and the struggle was not especially hard, though it stayed deep and long within themselves. From this myriad experience of place and people they embarked on a journey in a different direction-but a natural one, that is, into the self-now helped along by a comparative edge, complete with the elements of confrontation, balance, familial roots and similarities. The border situations afforded them the time and luxury of returning into their inner beings-their deepest thoughts about life, differences and similarities. This is important for the original poet-a gift of the border zone and of dislocation.

Many are the real images that are carved out of their own "confrontation" with Indonesia. Some are harsher and sometimes difficult-especially in the lines of Baha Zain. But one must also not forget the images of beauty and art which were carved with a greater intensity than they had in Malaysia.

As a side product of poetry they found subconsciously a new way of looking at the motherland and their own Malay language-along with a 
new or different way of looking at Indonesia. These poets did not reject Indonesia, in fact it became a great source of inspiration for their works. They found exceptional images, ideas and people as they had never found in their own country.

Oftentimes the poet felt a desire to find a place beyond difference-and climb into a world of universal meaning that may be shared not only by the two countries bordering the Straits of Melaka, but also leapfrog to the readership of other countries, that is, the international readership.

His words are more considered and he has given a maturity to a style he had just begun to write in, back in Malaysia. This was a style that conveyed the thoughts of the poet and the essayist/critic. The poems were longer and written to narrate complex situations. Perhaps images were their points of reference but the ideas were apparently wrapped around them.

So too for Siti Zainon who began to write seriously only in Jogjakarta, and also to create her own quiet style of description. This style was brought back to Malaysia and developed further to describe other situations and other lands.

The poet is the agent of sharing in the borderland and learns to understand the other and take the best of two worlds, and consequently to weave a shared world. He or she studies and attempts to understand the other and eventually become a bigger person, a poet sitting astride two countries and cultures, and read perhaps in Malaysia, Indonesia and beyond.

Interestingly, although there have been many political spats and misunderstandings between Indonesia and Malaysia, as far as we know there has never been any among their writers. This is a fact worth pondering.

\section{REFERENCES}

Alexander, Meena, 2009. Poetics of Dislocation. Ann Arbor: University of Michigan Press.

Arctic University of Norway, "The Border Aesthetics Project" in (http://en.uit.no/ prosjekter/prosjekt?p_document_id=344772).

Andaya, Leonard, 2008. Leaves of the Same Tree. Honolulu: University of Hawaii Press.

Baha Zain, 1974 . Perempuan dan Bayang-bayang. Kuala Lumpur: Dewan Bahasa dan Pustaka.

Baha Zain, 2008. Postponing Truth and Other Poems. Translated by Muhammad Haji Salleh. Kuala Lumpur: Dewan Bahasa dan Pustaka. 
MALAY LITERATURE VOLUME 28 NUMBER 12015

Baha Zain, 2014. Interview. Gombak, Kuala Lumpur. 3rd July.

Bhabha, Homi, 1994. The Location of Culture. London: Routledge Classics.

Hamzah Hamdani (ed.), 1980. Esei Sastera Baharuddin Zainal. Kuala Lumpur:

Dewan Bahasa dan Pustaka.

Muhammad Haji Salleh, 2009. An Introduction to Modern Malaysian Literature. Kuala Lumpur: ITBM.

Sakinah Abu Bakar, 2013. Silang Seni Siti Zainon Ismail. Kuala Lumpur: Dewan Bahasa dan Pustaka.

Siti Zainon Ismail, 1992. Bunga-bunga Bulan. Kuala Lumpur: Creative Enterprise. Pustaka.

Siti Zainon Ismail. 2004. Witir Sela Merapi. Bangi: Galeri Melora.

Siti Zainon Ismail, 2014. Personal Communication. 10-11 July. 